\title{
Challenging the State: Devolutionary Tenure Transitions for Saving and Expanding Forests
}

\author{
Liz Alden Wily ${ }^{1}$ (D) \\ Accepted: 1 April 2021 / Published online: 3 May 2021 \\ (c) The Author(s) 2021
}

\begin{abstract}
I address a contentious element in forest property relations to illustrate the role of ownership in protecting and expanding of forest cover by examining the extent to which rural communities may legally own forests. The premise is that whilst state-owned protected areas have contributed enormously to forest survival, this has been insufficiently successful to justify the mass dispossession of customary land-owning communities this has entailed. Further, I argue that state co-option of community lands is unwarranted. Rural communities on all continents ably demonstrate the will and capacity to conserve forests - provided their customary ownership is legally recognized. I explore the property rights reforms now enabling this. The replication potential of community protected forestlands is great enough to deserve flagship status in global commitments to expand forest including in the upcoming new Convention on Biological Diversity (CBD).
\end{abstract}

Keywords Forest tenure $\cdot$ Customary tenure $\cdot$ Land reform $\cdot$ Collective titles $\cdot$ Community lands

\section{Context}

"We lost a football pitch of primary rainforest every 6 seconds in 2019" concluded the World Resources Institute in June 2020 (WRI 2021). This was an increase of $2.8 \%$ on 2018. The highest loss of 11.9 million hectares occurred in tropical countries. Resulting carbon emissions equalled that of 400 million cars. Forest clearing for large-scale agriculture was identified as the main cause.

Global commitment to limit forest loss for watershed protection, biodiversity loss, and to mitigate climate change has grown exponentially since 1992 when 168 nations signed up to the first Convention on Biological Diversity (CBD) in Rio. Impacts of forest losses on nature and society are now better understood. Popular inclusion in forest conservation has risen as governments work more actively with local resource-dependent populations. Strategies to keep citizens out of forests has shifted towards their engagement as conservators in their own right (FAO 2016).

Liz Alden Wily

lizaldenwily@gmail.com

1 Van Vollenhoven Institute for Law, Governance and Society, Leiden Law School, University of Leiden, Box 9520,

2300 RA Leiden, The Netherlands
Global recognition of the role of secure tenure is only slowly evolving to better underwrite this trend. The UN General Assembly recognized that secure community land tenure is a functional element of success in forest preservation (UN 2012). Secure customary tenure was made a target of Sustainable Development Goals. However, this is not explicitly adopted into Goal 15 for achieving more sustainable terrestrial ecosystems. The relevant target 15.6 falls back on the old mantra of purchasing support for state conservation through availing more access and sharing benefits with affected communities (UN 2015).

This is curious as communities on all continents have established themselves as viable forest owner-conservators since Rio, as outlined below. But this practice has not been absorbed in the strategy that 197 government members of the United Nations are being asked to sign up to in a new post-2020 Convention on Biological Diversity. On the contrary, UN policy direction suggests vesting yet more existing and potential forests in governments to achieve protected area coverage over 30\% of the Earth's area (UNEP 2020). This path has prompted demand by civil society actors that safeguards must be instituted to limit a new era of forced displacement of customary landholders. Coalitions demand that an increase in the area of legally acknowledged community lands be adopted as a conservation strategy (ICCA 2020; MRG et al. 2020; RRI 2020a). A number of forest 
scientists agree (Erbaugh et al. 2020), especially as between 1.65 and 1.87 billion community members live within areas critical for biodiversity that are most likely to be earmarked for expanded protection (RRI 2020a). Of these, 363 million already live within existing protected areas (RRI 2020a). The majority have been deprived of tenure and other consequent livelihood, socio-cultural, and other rights in these areas (ibid).

The international community as represented by governments will determine the final strategy in Kunming in China in May 2021 at the Convention on Biological Diversity (CBD COP 15). This will influence decisions at the following UN Climate Change Conference in Glasgow in the United Kingdom in November 2021. Both fora are scheduled to involve 197 state parties.

\section{Argument}

I propose here that communities rather than governments should be the major cohort of forest owner-conservators by end of the century and that this should be nurtured and reflected in commitments towards mitigating climate change and its financing by governments. I find that the safeguards for millions of community members in the pursuit of the expansion of protected areas are inadequate, and even dangerous in not challenging the assumption that only governments can have tenure rights over and conserve protected areas. This is provocative in the twenty-first century where inclusion of the majority, and empowerment of their voice have come so forcefully to the fore in the democratization of agrarian societies in forest-rich tropical and sub-tropical zones. However, I also conclude that demand for radical expansion of recognized community land ownership by indigenous peoples, African descendants, and other communities falls short. This relates to implied assumption among advocates of community land security that recognition of community land ownership will itself deliver resource conservation. This is not always the case, as Seymour et al. (2014) reported in a literature review on the subject. While secure ownership indisputably prompts commitments to caring for one's property, and its absence constrains this incentive, it is sensible for global investment to additionally require and promote interventions that assist communities to consciously prescribe mechanisms to ensure existing and new forests on their lands can and will be nurtured. A practical existing construct rests in zoned and mapped 'Community Protected Forests' described below.

One reason for this position is that while indigenous forest peoples around the world have strong socio-cultural, identity, and livelihood reasons for saving their forests, even they may experience internal and external pressures, including their own expanding cultivation for food security. Another reason is that expanding forests require large numbers of farming and agro-pastoral communities in addition to forest peoples to make a difference. Balancing needs for cultivation, pasturage, and forests requires an inclusive and integrated approach, elemental to landscape approaches and large-scale land and forest restoration initiatives (Reed et al. 2016; Hallet and Mumba 2020). These fit well with simpler and cheaper localised zoning of forest lands by communities during identification and titling of their community domains, as also elaborated in this paper.

Blunt approaches to community rights recognition rarely overcome conflicts that have been allowed to fester through legal neglect, or that have been reinforced by external actors and investors seeking to secure their own land interests. Customs can themselves be unjust. It is quite common for conflicts to arise over inter-community boundaries, community membership (especially in respect indigenes and 'strangers'), or over rights acquires through class formation and elite capture, when communities are given the opportunity to secure collective ownership over their customary domains inclusive of forest, rangeland and other commons. Peters and Kambewa for Malawi (2007), Wainwright and Bryan for in regard to inter-community conflicts during community mapping in Nicaragua and Belize (2009), and Krantz for Mozambique (2020) document such examples. It is unsurprising that community land laws increasingly stipulate social justice and equity procedures as integral to community rights recognition. Official and civil society guidelines also take pains to guide communities on how to overcome contestation and to whom to turn for external facilitation (e.g., United Republic of Tanzania 2011a, b; Namati 2017).

To recap, the social safeguards required to limit expansion of state protected forests into community lands need tangible mechanisms to guide and empower communities as conservators at the same time. A strong role for communities as forest guardians and producers is reinforced by the above-mentioned geography wherein more forest already exists in the claimed community landholding sector than in the state domain (RRI 2020a). There is also an unfortunate absence of evidence that government forests are effectively protected in tropical and sub-tropical zones, the site of most forest loss (IPBES 2019). Breakdown of losses suggest as much forest is being lost from national forest parks and reserves as from lands outside them (FAO 2018). Denial of local tenure, evictions, and diminishment of access and use predictably disposes aggrieved communities to unlawfully enter and exploit forests lost to them. I have experienced this first-hand on occasions where declaration of new national forest reserves absorbing the traditional forests of communities prompts a rush to 'get what we can from our forests 
before they are taken from us' (Alden Wily 2011). State forests routinely proclaimed as in the public interest of the national community can also be readily reconstructed as meaning everyone and no one owns and can use them (ibid).

As indicated above, there are also good governance reasons why a focus on empowering communities is timely in global and national strategies to retain and multiply forest cover. This stems in large part from several decades of uneven but persisting democratization in developing economies (Haggard and Kaufman 2016). This is complemented by a corollary era of new constitutionalism providing more inclusive bills of rights for disadvantaged groups and poor communities (Alden Wily 2018a for Africa; Greene and Khosla 2018 for Asia; Negretto and Couso 2018 for Latin America). There is also popular frustration with mass globalization as it fails to enhance majority empowerment or to limit state powers as promised in land-rich poor economies (McKeon and Berron 2020).

The policy trajectory in the forest sector has inevitably been impacted. Cracks in the twentieth century bulwark of state forest landlordism and militant governance are widening. Property rights reform is a tangible driver. This is not to say that community owned forestlands are the only path to a larger and stronger forest resource or even viable in all circumstances. Nor do I suggest that most existing state-owned protected forests be turned over to communities. I do, however, suggest that a strategy narrowly focused on improving the capacity of governments to expand forests is misplaced and cannot deliver to the degree needed. Community owned protected forests deserve equal emphasis and investment under the banner of climate change mitigation and achievement of development goals for society and nature.

Finally, a reminder of the themes emerging in this Special Issue collection encapsulated by Pain et al. 2020 in their introductory paper; they first suggest that forest conservation and expansion cannot practically succeed through a narrow resource-based focus that does not allow for the difficulties faced by millions of smallholders and other land-dependent communities with uncertain futures in either the agrarian or urban economy. This links to an identified need to depart from orthodoxies promoting the primacy of pristine and presumed unchanging primary forests, relegating secondary growth forests to lowlier status. Using modern forest science, they show how this misrepresents the inherent mobility of so-called primary forest and identifying forest succession as a diverse and multi-functional landscape. Already, forests classified by FAO as primary constitute only $36 \%$ of forest area and declining (FAO 2016). Excellent examples of recovering and new forests are provided in this issue from Nepal, Peru, and Ethiopia. New growth as compared to old growth forests abound in the community land sector discussed here.

\section{Approach}

This paper is presented as a perspective piece on the role of tenure in saving and expanding forests. I draw on a desk review to assess the legal opportunities for communities to own forests, and the environmental and developmental outcomes thus far. I draw on my own practitioner experiences where these have concerned forest tenure in 14 states. I begin with an explanation of what is meant by the community land sector, and an assessment of probable forest cover within this domain. I then examine land tenure reform and its reach as so far in prompting and enabling community owned forest reserves, before turning the analysis to the state-owned Protected Forests sector; this is with a view to gauging how far restitution of such lands from governments to communities is occurring. I present an illustrative case from Kenya.

\section{Background: The Community Land Sector and its Forests}

The community land estate refers to community-owned lands held under customary, neo-customary or state law tenure, whether these are, or are not, presently acknowledged as properties. The domain is vast, at an estimated 5-6 billion hectares or half the planet's land area (RRI 2020b). Most community lands are made up of mainly rangelands, forests of all types, seasonally used arid and swamp lands, and mountains. Settlements and farms may anchor a community land area but, excepting the most fertile terrains, farms tend to absorb only a tiny percentage of each community's domain or property. Retention and care of forests within the community land sector is mixed. Farmers have historically been blamed for clearing forests to farm but do not compete by any measure with the millions of hectares cleared annually by commercial logging, for cattle ranching, and for mining and oil palm plantations (FAO and UNEP 2020).

Most community land is held and used by landdependent communities according to customary norms or, more accurately, under hybrid traditional-modern norms that reflect the well-known adaptability of community-based systems of tenure and land use to changing conditions (Alden Wily 2020). Communities vary widely in size but probably number around 5 million discrete entities, with up to 3 billion members in 2021 . They include 200 million rural Afro-descendants in the Americas, 400 million community members who identify as Indigenous Peoples with ancient occupation histories, and up to 2 billion members of communities with less ancient customary land occupation histories, in especially Africa and Asia. There are in addition possibly 
600 members of purpose-built land cooperatives or collectives; these have been principally developed to counter mass landlessness and land poverty under feudal regimes (Alden Wily 2018b). The prime example is China where more than half a billion rural Chinese belong to one million collectives, covering nearly half of China's land area today (Li et al. 2020).

While differences exist among these sub-sectors of community landholding, all share founding features of community-based property systems; they own the soil or the right to the soil in undivided shares. They govern the use and disposal of the land themselves, although with high dependence upon traditional norms at one extreme and adoption of state-dictated norms at the other. Most communities devise rules of access and use and other rights that distinguish between private rights allocated to individuals or families to exclusively use a plot for a homestead, business, or farm, and undivided common assets. This distinction is least common among hunter-gatherer and pastoralist communities (Alden Wily 2012). Recognition by national law of communities as lawful owners is rising. Sampling suggests that $18.7 \%$ of global land area in 2015 was legally recognized as community property or as public lands formally designated for exclusive community use (a sample of 64 states) (RRI 2015a). This was revised upwards in 2020 to $26.3 \%$ for 42 countries (RRI 2020b).

\section{Forest within the Community Land Sector}

Estimates of how much of the community domain is forested can be obtained by excluding sectors least likely to be present in the community land sector: plantations at 291 million hectares and protected forests at 651 million hectares subtracted from a global forest estate of 3.99 billion hectares (FAO 2016). This suggests an existing community forest estate of 2.7 billion hectares. Nevertheless, only $12.2 \%$ of this forestland was legally owned by communities in 2017 according to a Rights and Resources Initiative analysis (RRI 2018) of forest tenure in 58 states. An additional 2.2\% of forests fell within public lands allocated to communities for their exclusive use. The total of 58 million hectares under community control covered only one fifth of forests within the community domain. Therefore four-fifths of forests customarily owned and controlled by communities were only available to them under permits or were inhabited and accessed unlawfully, an unfavourable condition on which to base custodianship. It is particularly important to observe that the potential for biodiversity protection is not limited to existing forests within community lands. Millions of additional hectares of forests could be created through natural regeneration or new planting to benefit community livelihoods and conservation.
The Trigger to New Paths to Conservation: Land Tenure Reform as Social Transformation

Setting aside significant early outliers such as Mexico's reforms begun much earlier in the 20th century, property reforms affecting customary and other community-generated land rights began to surge in the 1980s. Broadly, these reforms entail abandoning widespread compulsory individualization and statutory titling of family lands, and formalized capture of communal assets as unowned, as launched midcentury by many governments, including in Africa (Bruce and Migot-Adholla eds. 1994). These so-called modernization reforms expanding privatization also aimed to end local land rights jurisdiction by incorporating the registration and regulation of new individualized property rights into state systems. Political democratization has been mentioned earlier as a prompt to new approaches, complemented by neoliberal demands by lending agencies for market-based land reform in borrowing developing economies; ironically, the latter often failed to deliver accelerated individualization as national governments responded to demands by investigating anew how majority customary rights should be handled, in due course forcing lenders themselves to amend their approaches to ubiquitous indigenous and other customary tenure systems (Deininger 2003). Other drivers included rising identification of Indigenous Peoples in international law amid territorial demands (UN 2009) and the ending of civil wars in land dependent countries where competition for communal lands had been a driving factor behind the conflict (Young and Goldman 2015). Post-Mao reforms in the 1980s in China and those following the collapse of the Soviet Union in 1991 also triggered comparable changes in rural land ownership (Lerman et al. 2002; Chun 2015).

Still, it may be argued that the most influential driver of change in the legal positioning of property relations has its deepest roots in a late-twentieth century burst of anticolonialism, feeding into or a result of the above drivers. This is particularly relevant when it is considered (as Wikipedia reminds us) that only 10 or so of today's 197 polities escaped European colonization. While post-independence governments largely sustained the legal notions of property adopted into colonial laws, impatience with this carryover was widely apparent from the 1990s. This is still proving infectious within regions (Alden Wily 2020).

From a long term perspective, the radical nature of present property reforms cannot be underrated. They signal a stark departure from the cornerstone paradigms established in Roman, then European, then globalised land law that property in land comes into being only at the decision and direction of the ruling State, and is by nature individual, exclusive, and until recently limited to male elites (ibid). Imposition of such norms through colonialism most undermined communal rights over shared resources beyond 
the house and farm. For while it was pragmatic for colonizers to allow the peasantry to farm to feed themselves, forests and other resource-rich assets were too expansive and valuable to allow local ownership to be recognized. Accordingly, they were defined in colonial statutes as unowned 'wastelands,' terres vacantes et sans maîtres, herrenlos, baldios, or mawaat, and the colonial government of the day empowered to dispose of them at will (ibid). Yet to generalize, region to region, these communal assets at community level were - and remain - the major reason why community property systems survived outside the law and remain critically relevant.

This also explains why a principal construct of contemporary reform is socially collective entitlement. This is sometimes delivered in plural forms to reflect distinctive conditions and demands. For example, in Peru, Bolivia, Colombia, and Brazil distinct versions of collective entitlement are issued to indigenous, intercultural, former slave, peasant farmer, and coastal communities (ibid). While land laws in Mozambique, Tanzania, Uganda, Liberia and Kenya provide only one form of collective entitlement, much is left up to the community to reshape the internal zoning and governance of the property in line with land types and land uses (Alden Wily 2020).

The convention that property is defined as alienable, an exchangeable commodity sight unseen through paper transfers, is also proving more easily delinked when it comes to registered collective property. New typologies are emerging that may define community ownership as inalienable and indivisible. The declaration that community lands such as those held under native title are 'inviolable,' 'unable to be seized,' 'extinguished,' or 'converted by governments' has been widely adopted as an added protection for Indigenous Peoples against external persuasion to sell or gift lands. Indigenous Peoples are also now making active use of a broader principle adopted into international law that governments must secure their free, prior, and informed consent to expand mining, plantations, or other state-endorsed developments into their forests and related common lands. Success is mixed (FPP 2021).

The reach of reforms around customary and other community-based property rights is greater than might be expected. This is clear in a study of 100 national land laws I conducted in 2018 (Alden Wily 2018b). Seventy-three percent of laws upgrade the status of customary land rights from permissive occupancy to legally supported ownership; 53\% of these laws were first enacted after 2000. Fifty-four of the 73 laws endow collective entitlements with equivalent protection granted to registered private properties. Constitutions led the way to reform in 33 of the 73 countries. The more radical constitution provisions turned communities living for generations on public, state, or comparable lands into lawful landowners; the case for customary communities in
Vanuatu, Laos, Kyrgyzstan, Ecuador, Uganda, Kenya, and Brazil. However, follow-up mapping and registration of each community's property is encouraged to double-lock this new status. In other new land laws, case by case formalization is the only route through which a community can secure legal recognition of ownership.

While the core elements of the reform are rights-based, good governance is enjoined. The requirement for communities to adopt fully inclusive decision-making has strengthened with each passing decade. Frameworks for this can be surprisingly similar. For example, new land laws as far apart as Vanuatu, Romania, India, and Tanzania all require the community to define co-owners as a community assembly, and which as the final decision-maker elects committees to serve as land administrators on their behalf. Recognition of communities as legal persons is also becoming simpler. The most recent paradigms remove the need for a community to expensively establish and manage complex corporate entities in which to vest collective title. They are either declared in law to be self-defining legal persons for purposes of registrable collective ownership or are registrable once they have listed every member of the comunity and commit to updating these registers annually. This opens the door to thousands of communities easily accessing collective entitlement. This departs from earlier arrangements whereby, for example, it may still take an Australian indigenous community over a decade, at great expense and unwanted dependence upon outside agencies to acquire land title under the Native Title Act 1993.

Collective land titling is not yet as expansive in Africa as in Latin America and parts of Asia. Yet customary tenure dominates over three quarters of the African continent, a figure including nomadic community claims in the Sahara Desert (Alden Wily 2020). As often the case in other regions, most of this domain comprises rangelands, swamplands, and forestlands. Today, 29 of 54 African country land laws provide for communities to secure collective title over their respective domains (ibid). The laws are most precise in 10 countries including those of the more recently enacted Community Land Act of 2016 in Kenya and the Land Rights Law of 2018 in Liberia. Uptake and state-supported implementation of laws is most advanced in Mozambique, Tanzania, and Uganda where similar laws were enacted in the 1990s. Nevertheless, loopholes are exploited even in these countries where governments and investors seek lands, increasing demand for new land valuation and compulsory acquisition procedures affecting community properties.

\section{Community Forest Ownership}

It has taken the forestry sector a long time to acknowledge secure tenure as a key to sustained community-based forest conservation as acknowledged by FAO in research covering 
$60+$ countries (Gilmour 2016). Engaging communities in reforesting lands began in the 1970s through on-farm tree planting schemes and communal woodlots. In the 1980s, strategies moved into benefit-sharing, community members securing use rights in return for reporting offenders to state foresters. Buffer zones for community use around protected forests were also common. Interventions were refined in the 1990s under state-people co-management and/or contractual regimes to enable communities to participate in harvesting. These were often bureaucratic and costly to manage and subject to conflict as creating an uneven playing field for officials and communities (ibid).

A more successful approach also gained ground in the 1990s that adopted community ownership as the foundation for new forest protection in The Gambia, Tanzania, China, Vietnam, and Mexico. The granting of native title to Indigenous Forest Peoples in Bolivia, Brazil, Colombia, and Peru as well as in Canada, Australia, New Zealand, and Papua New Guinea provided a parallel path to pursue community forest ownership. By the 12th World Forestry Congress in 2003, owner-conservator conservation by communities was high on the agenda and subject to proactive resolutions (Sayer 2005). Tracking of forest tenure was launched, initially by Forest Trends and since 2008, by the FAO and the Rights and Resources Initiative.

Powerful examples of community owned forests are documented in all regions including Africa, notably in Tanzania, which during the 1990s and 2000s enabled 580 villages to set aside 2.3 million hectares of forestlands as protected community forest reserves (United Republic of Tanzania 2012). A further $500+$ communities were designated as official custodians of 3 million hectares of nationally important catchment forests adjacent to their lands. Gilmour (op cit) also reported that The Gambia has systematically transferred ownership to 500 communities since 1998. Namibia had registered 320,000 ha as community owned forests by 2013 . He concluded that secure ownership was indeed a key trigger to sustainable community forest protection. Other agencies echoed this finding (IFRI and RRI 2016; Larson and Springer, 2016; IIED, FPP and RFUK 2019; World Bank 2019).

While success is not total, most research favourably compares the impact on forest recovery in community-owned with state-owned and controlled forests (Bluffstone and Robinson 2015; Cronkleton et al. 2017). Research in Bolivia, Brazil, Colombia, and Guatemala has shown that forest loss is two or three times more in state forests (Blackman and Veit 2018). The demand for secure tenure is rising where communities have shown themselves to be effective forest developers and custodians at scale, as in Nepal (Pathak et al. 2017). Demand is also surging where communities find they are unable to withstand state-supported allocation of their forests for large-scale oil palm plantations and mining in particular, such as documented by The World Bank in Zambia (Ali et al. 2019) and by Chase Smith (2020) for Peru. Scientific studies add force to the growing preference for tenure-based approaches to limit encroachment, fires, and logging, while also securing livelihood support for communities (Levy-Tacher et al. 2019; Oldekop et al. 2019; Tseng et al. 2021). Research on the expansion of mining and its impacts upon forests and biodiversity calls for community land ownership as a means to help contain losses (Meijaard et al. 2020; Vallejos et al. 2020). In 2019 a group of 20 geospatial scientists and the Intergovernmental Panel on Climate Change independently concluded that secure customary tenure has strong potential to advance climate mitigation at scale (Garnett et al. 2018; IPCC 2019). These conclusions have been added to since. Most recently, a new UN report shows evidence that indigenous and tribal peoples are the best guardians of forests in Latin America and the Caribbean (FAO 2021).

\section{Community Ownership of Protected Areas}

The degree to which communities may become owners of existing or new protected forest areas remains a contentious issue that is finding a global focus as biodiversity and climate change mitigation plans are finalized. Demarcation of new state forest reserves is rising often provoking conflict with customary owners. Over 50 new national forest reserves have been gazetted in Kenya alone since 2016 raising ire among local communities (FPP 2020). 'Green grabbing' and 'conservation refugees' are now common terms in most regions and 'environmental peacebuilding' has significantly expanded as a discipline (Ide et al. 2021).

A logical step is to formally delink the status of forest or potential forest land as protected, from its ownership, to achieve both expanded protection and rights, as these cases illustrate: all protected forests are owned by communities in Papua New Guinea, 44\% of Australia's protected forests are owned by Indigenous Peoples; 190,000 ha of reserved forests are owned by communities in Cambodia; and 84 of 221 Ancestral Domain Titles issued to Indigenous Peoples overlap Protected Areas in the Philippines (Quizon and Marquez 2019). Land restitution to Indigenous Peoples in Latin America absorbed 46 forest reserves under 37 indigenous territories, 24 national parks overlap indigenous or Afro-Colombian community lands in Colombia, and $31 \%$ of Indigenous Peoples lands overlap protected forests in Mexico (RRI 2015b). In such cases, communities may even find it advantageous to seek designation of their lands as Protected Areas to help limit encroachers and state projects. The Yaigoje Apoporis National Natural Park in Colombia is a case in point; 19 indigenous communities sought protected area status to limit mining (Rainforest Concern 2019). Costa Rica now recognizes that community property may 
be subject to protection orders rather than taken from the community (Castro-Arce and Vanclay 2020). This has been accepted strategy in Europe for some time (European Union 2020). In Romania, for example, 225 of 1500 communityowned forests and pastures have been declared in areas that also retain status as national parks, nature reserves, or scientific reserves and vice versa (Vasile 2019). The Romanian Government views community ownership as enhancing protection against illegal logging, the major threat.

Nevertheless, most past and new creation of Protected Areas involves dispossession and is a conflicted subject for millions of community owners of forested lands or land that can be reforested. Therefore, while the Indonesian Government has pledged to enable 704 Indigenous communities to secure title over their 7.76 million hectares of forestlands, entitlements are to exclude State Forests (Anggraini and Lathifa 2017). In India, The Scheduled Tribes and Other Traditional Forest Dwellers Act of 2006 enables millions of forest people to secure use and occupation rights as individuals, families or groups to live within and around some 500 wildlife sanctuaries and 90 national parks but stops short of vesting title in these communities (Menon 2019). Also, while $58 \%$ of all forests are owned by village land collectives in China (90 million hectares), these are mainly plantations (Xie 2015). In contrast, all Protected Forests belong to the Chinese Government.

In Africa, thus far only South Africa has restored ownership of several forest reserves to communities, although retaining state agency management (Thondhlana and Cunhill, 2017). Mainland Tanzania land law (1999) draws a clear distinction between village (community), private, and general (public) property. Protected Areas may be declared and owned in any of these classes. The subsequent forest law (2002) declared devolution of forest authority to the most local level possible a core objective. In practice, while declaration of protected forests on acknowledged village lands thrives, the Tanzanian Government has not yet restored several hundred National Catchment Forests already managed by adjacent communities to this status. Nor has the Liberian Government facilitated regularization of acknowledged community ownership of many of the 11 National Forests declared on their lands in 1960. As new forest and protected area legislation has evolved since 2003 alongside forest and land rights laws $(2009,2018)$, community owned protected areas have been more formally confined to lands over which communities may secure title and secondary to the priority of state-owned protected areas (Lomax and Warner 2021). In Ghana, where natural forest falls entirely within acknowledged customary lands, exploitation, protection, and management were vested in the state forest authority in the 1980 s, a fixed percentage of harvesting income reaching communities only indirectly through local governments and chiefs. Sub-Saharan states have made progress in enabling communities to designate protected forests on acknowledged local lands, but contention as to ownership of existing protected areas remains with little sign of concession, the poor condition of so many national protected forests notwithstanding.

\section{Forest Peoples and Protected Areas}

This is particularly consequential for Indigenous Forest Peoples in Africa. Together they constitute a tiny minority of only one million Africans living mainly in five Congo Basin countries with smaller populations in five East African countries. Many live unlawfully today within Protected Forests as the last available lands within their once vast territories that have been lost to them through allocation to settlers, logging companies, and stronger tribal groups needing more lands to clear and farm. Forest Peoples have watched Protected Forests decline in area and quality under state owner-management. By their own admission Forest Authorities in Uganda and Kenya count loss to protected areas as around 30\% since 1990 (Republic of Uganda 2016; Republic of Kenya, 2018a, b). Their conscious role in unsustainable exploitation and excisions for other purposes is clear.

The African Court of Human and Peoples' Rights acknowledged this in its judgement against the Government of Kenya in 2017 in a case brought by the Ogiek Forest People, wrongly accused of degrading the Mau Forest Complex and protesting repeated eviction (African Court 2017). This ruled that the Ogiek are the lawful owners of the Complex and that they must be equitably consulted in any remedy determined upon (OPDP et al. 2020). Having failed to come to agreement as to remedy, the African Court is scheduled to consider the plans of the Ogiek and Government in 2021. In its actions so far, the Government intends to carve out a small proportion of the most degraded land for Ogiek to settle on as farmers, retaining 95\% of the Complex as public property vested in its Forest Agency (Republic of Kenya 2020).

Ogiek, and the four other forest peoples in Kenya plead that community ownership is a viable route to restore the badly degraded state assets wherein they remain unlawful occupants. They emphasise irrevocable attachment to their ancestral homeland forests, their persisting need for forest to be kept intact for socio-cultural and identity purposes and to sustain and expand their core livelihood activity of forest beekeeping (Mau Ogiek 2019). They and others confirm that this requires intact forest to flourish (Blackburn 1982). They offer in writing that restored ownership under collective land titles as provided for by Kenya's Community Land Act 2016 may legally exclude a right of alienation, to demonstrate their comitment to retained their ancestral forest environment for time immemorial; that conservation orders may 
forbid clearing of any existing forest, require habitation to be limited to agreed anturally unforested glades and moorlands, and require community owners to restore degraded forests where the community and the Forest Service agree this is viable (ibid). Additionally, Mau Ogiek seek to establish Protected Forests within their community lands.

The Mau Ogiek also demand that Government remove thousands of farmers permitted to invade and clear much of their ancestral territory for farming, including those unlawfully issued title deeds as the Government itself documented (Republic of Kenya 2009). Ogiek also insist that the Forest Service cease clearing indigenous forests for exotic plantations and the system whereby forest staff receive payments from external interest groups who register themselves as Community Forestry Associations in order to gain access to state protected forests for these purposes.

The above demands are reiterated by all Kenya's forest peoples, in addition to forest peoples in Uganda. There, Benet Ogiek and Batwa Pygmy forest peoples also ancestrally live in Protected Forests in respectively the far east and far west of Uganda. The latter submitted a restitution claim to the Uganda Constitutional Court in 2019, still to be heard. Pygmy communities have made a similar submission to the Court in the Democratic Republic of Congo (DRC) in respect of their ancestral territory of Kahuzi Beiga National Park. In June 2020, the National Assembly of DRC voted unanimously in support of a Bill Protecting and Promoting the Rights of Indigenous Pygmy Peoples, still to be approved by the Senate. If enacted, this secures their right to traditional lands and provides expansively for free, prior and informed consent prior to relocation or other state-endorsed encroachments. Baka Pygmy communities evicted from two reserves are in process of seeking their restitution in Cameroon. The Republic of Congo (Brazzaville) in Law No. 5 of 2011 Concerning the Rights of Indigenous Peoples, has made provisions for forest peoples to secure exclusive title to ancestral territories, but this law is yet to be applied ten years on.

Clearly, African Forest Peoples have become more connected among themselves. They have also been able to draw upon the progressive laws and achievements of forest people in Latin America, including globally publicized NASA satellite imagery illustrating that only forest peoples' territories, and most notably the 11 million hectares territory of the Kayapo were successfully protected by their owners from raging fires during 2019 (Zimmerman 2019). They are most recently encouraged by a Judgement of the Inter-American Court of Human Rights in February 2020 that ruled that the ancestral lands of 132 indigenous communities in Argentina must be restored to them within six years and outsiders including those holding private title, resettled (IACHR 2020). They hope for a similar decision by the African Court of Human and Peoples' Rights in 2021 in agreement that the
Mau Forest Complex be restored to forest people ownership subject to conservation conditions, rather than forced to settle and assimilate as farmers on allocated farm plots.

\section{Conclusion}

The right of indigenous forest peoples and other rural communities to hold existing or potential forests within traditional lands is evolving as a practised legal norm. Everywhere the construct of collective land entitlement to nest this provision is advancing, albeit not without pushback as illustrated in this paper, as governments find it unpalatable in practice to surrender forests and other valuable lands to their poorest rural communities. How far the landlordist convictions of colonial and post-colonial administrations can be sustained further into the twenty-first century is moot. At this point, national and draft global strategies to limit carbon emissions by expanding forests under state ownership, remain strong. Nevertheless, this is less and less easy to sustain in many countries as rural communities become more conscious of and empowered to seek remedy for what they often now see as their fruitless dispossession of forestlands in the name of protection, and which has not occurred, and as they resist more losses for this unjust cause. Their own rising awareness, empowerment and voice, are also not easy to put back in the box, especially as rights around this are being legally entrenched in the name of more inclusive democratization.

For as long as barriers and roadblocks are constructed to limit majority rural rights to their lands and resources, state-people contention will fester. As a critical resource for so many millions, forests, like rangelands have moved full square into this conundrum. The fact remains that successful expansion of forest cover in the most vulnerable tropical and sub-tropical zones is unlikely to succeed without such land rights adjustments. While it is unlikely that communities will ever be majority forest owners around the world, it is realistic to predict a steady rise in this direction. In the interim, lines between the forests and forest-able lands of governments and communities are being firmly drawn, in what may prove to be a backward step for conservation and climate change mitigation. Forest peoples may be the only sector within rural populations to see restitution of ownership of existing Protected Areas, and the conditions imposed upon them as owner-conservators may be engineered to be too onerous to sustain. State sponsorship or consent to largescale forest clearance for oil palm, cattle ranching, and mining may also truncate community forestland rights in many countries for several decades. However, even this could alter as more forest authorities see the benefits of focusing on their regulatory and advisory service roles to citizens as private and community owners of protected forests. 
Cost-efficiency, experienced decline in conflict around forest tenure, the empowerment and connectedness of rural communities, and sustained pressure for fair governance should persuade policy makers and legislators that a communitybased route to forest protection is long overdue.

\section{Declarations}

Conflict of Interest The author declares she has no conflict of interest.

Open Access This article is licensed under a Creative Commons Attribution 4.0 International License, which permits use, sharing, adaptation, distribution and reproduction in any medium or format, as long as you give appropriate credit to the original author(s) and the source, provide a link to the Creative Commons licence, and indicate if changes were made. The images or other third party material in this article are included in the article's Creative Commons licence, unless indicated otherwise in a credit line to the material. If material is not included in the article's Creative Commons licence and your intended use is not permitted by statutory regulation or exceeds the permitted use, you will need to obtain permission directly from the copyright holder. To view a copy of this licence, visit http://creativecommons.org/licenses/by/4.0/.

\section{References}

African Court. (2017). Ruling of Application 006/2012 African Commission of Human and Peoples' Rights v Government of Kenya. African Court of Human and Peoples' Rights, Arusha.

Alden Wily, L. (2011). The Tragedy of Public Lands: Understanding the Fate of the Commons under Global Commercial Pressure. International Land Coalition, Rome.

Alden Wily, L. (2012). Customary Land Tenure in the Modern World. Rights to Resources in Crisis: Reviewing the Fate of Customary Tenure in Africa. Briefs 1-5. Rights and Resources Coalition, Washington DC.

Alden Wily, L. (2018a). Compulsory Acquisition as a Constitutional Matter. Journal of African Law 62(1) 2018: 77-103.

Alden Wily, L. (2018b). Collective Land Ownership in the $21^{\text {st }}$ Century: Overview of Global Trends. Land 7(2), 68.

Alden Wily, L. (2020). 'Adjusting to New Era Agrarianism: Tackling the Troubled Interface of Public and Community Property'. In Land Reform and Economic Development in Africa: New Ideas, Opportunities and Challenge. African Development Bank, Abidjan, pp. 57-69.

Ali, D., Deininger, K., Hilhorst, T., Kakungu, F., Yi, Y. (2019). Making Secure Land Tenure Count for Global Development Goals and National Policy. Policy Research Working Paper No. 8912. The World Bank, Washington DC.

Anggraini, N., and Lathifa, U. (2017). Communal Rights in Land: Indonesia Government Effort to Protect the Rights of Indigenous Groups. International Journal of Social Science and Humanity 7 (8): 513- 517. At: http://www.ijssh.org/index.php? $\mathrm{m}=$ content\&c= index\&a=show\&catid=91\&id=1247. Accessed 2 Oct 2020.

Blackburn R. (1982). In the land of milk and honey: Ogiek adaptions to their forests and neighbours. In E. Leacock \& R. Lee (Eds.), Chapter 6 in Politics and history in band societiest. Cambridge: Cambridge University Press.

Blackman, A., and Veit, P. (2018). 'Titled Amazon Indigenous Communities Cut Forest Carbon Emissions'. Ecological Economics 153: 56-67.
Bluffstone, R., and Robinson, E., (Eds.). (2015). Forest Tenure Reform in Asia and Africa: Local Control for Improved Conservation. RFF Press, London.

Castro-Arce, and Vanclay, F. (2020). Community-Led Green Land Acquisition: Social Innovative Initiatives for Forest Protection and Regional Development. Land 2020(9): 109.

Chase Smith, J. (2020). We Are Here: The State of Community Based Landscapes in Peru. In N. Robins and B. Fraser (Eds.), Landscapes of Inequity: The Quest for Environmental Justice in the Andes/Amazon Region. University of Nebraska Press, Lincoln.

Chun, L. (2015). 'Rethinking Land Reform: Comparative Lessons from China and India'. In The Land Questions: Socialism, Capitalism and the Market. Makerere Institute of Social Research, Kampala, pp. 95-157.

Cronkleton, P., Artati, Y., Baral, H. et al. (2017). How do property rights reforms provide incentives fore forest landscape restoration? Comparing evidence from Nepal, China and Ethiopia. International Forestry Review, 19(S4).

Deininger, K. (2003). Land Policies for Growth and Poverty Reduction. The World Bank and Oxford University Press, Washington DC.

Erbaugh, J., Pradhan, N., Adams, J., Oldekop, J., Agrawal, A., Brockington, D., Pritchard, R. (2020). Nature Ecology \& Evolution, (4): $1472-1476$.

European Union 2020. The European union and forests. Fact sheets on the European Union. European Parliament. https://www.europarl. europa.eu/factsheets/en/sheet/105/the-european-union-and-fores ts. Accessed 15 Mar 2021.

FAO. (2016). Global Forest Resources Assessment 2015. How Are the World's Forests Changing?, 2nd edn., FAO, Rome.

FAO. (2018). The State of the World's Forests - Forest Pathways to Sustainable Development'. FAO, Rome.

FAO. (2021). Forest governance by indigenous and tribal peoples. An opportunity for climate action in Latin America and the Caribbean. FAO, Santiago.

FAO and UNEP. (2020). The State of the World's Forests 2020. Forests, biodiversity and people. FAO and Nairobi, UNEP, Rome.

FPP (Forest Peoples Programme). 2020. Kenyan communities report illegal evictions during COVID-19. Press Statement 23 July 2020, Nairobi. hhttps://www.forestpeoples.org/en/CLAN-press-releaseKenyan-communities-report-illegal-evictions-during-covid 19. Accessed 31 Aug 2020.

FPP (Forest Peoples Programme). (2021). Rolling back social and environmental safeguards. At: http://www.forestpeoples.org/en/ rolling-back-safeguards.

Garnett, S.T., Burgess, N., Fa, J. et al. (2018). A spatial overview of the global importance of Indigenous lands for conservation. Nature Sustainability 1 (2018): 369-374.

Gilmour, D. (2016). Forty Years of Community Based Forestry. Forestry Working Paper 176. Rome, FAO.

Greene, J., and M. Khosla (2018). Constitutional rights in South Asia: Introduction. International Journal of Constitutional Law 16 (2): 470-474. https://doi.org/10.1093/icon/moy043.

Haggard, S., and Kaufman, R. (2016). Democratization During the Third Wave. Annual Review of Political Science 2016. 19:125-44.

Hallet, J., and Mumba, M. Eds. (2020). Restoring the Earth - the next decade. Unasylva Vol. 71 2020/1.

IACHR (Inter-American Court of Human Rights). (2020). Judgement of February 62020 in the Case of the Indigenous Communities of the Lhaka Honhat (Our Land) Association v. Government of Argentina. (Official English translation).

ICCA Consortium (Indigenous Community Conserved Areas) (2020). Comments submitted on the draft monitoring framework for the post-2020 global biodiversity framework. ICCA, Geneva. 
Ide, T., Bruch, C., Carius, A., Conca, K., Dalbelko, G., Mathew, R., Weinthal, E. (2021). The past and future(s) of environmental peacebuilding. International Affairs 9(1) January 2021: xi-xvii.

IFRI \& RRI. (2016). The Science Is In: Community Governance Supports Forest Livelihood and Sustainability. RRI, Washington DC.

IIED, FPP and RFUK (International Institute for Environment and Development, Forest Peoples Programme, Rainforest Foundation UK). (2019). Securing customary rights is key to sustainable community forestry. Briefing, United Kingdom.

IPBES (Intergovernmental Science-Policy Platform on Biodiversity and Ecosystem Services). (2019). Summary for Policymakers of the IPBES Global Assessment Report on Biodiversity and Ecosystem Services. IPBES Secretariat, Bonn.

IPCC (International Panel of Climate Change). (2019.) Special report on climate change, desertification, land degradation, sustainable land management, food security, and greenhouse gas fluxes in terrestrial ecosystems. IPCC.

Krantz, L. (2020). Applying a Community Based Approach to Tenure Formalization. A Case Study from Northern Mozambique. Working Papers in Human Geography. Goteborg University, Goteburg.

Larson, A., and Springer, J. (2016). Recognition and Respect for Tenure Rights, Natural Resource Governance Framework Paper. IUCN, CEESP, CIFOR, Bogor.

Lerman, Z., Csaki. C., Feder, G. (2002). Land Policies and Evolving Farm Strutures in Transition Countries. The World Bank, Washington DC.

Levy-Tacher, S., Ramirez-Marcial, N., Navarette-Guitierrez, D., Rodrigues-Sanchez, P. (2019). Are Mayan community forest reserves effective in fulfilling people's needs and preserving tree species? Journal of Environmental Management, 245: 16-27.

Li, L., Tan, R., Wu, C. (2020). Reconstruction of China's farmland rights system based on the 'trifurcation of land rights' reform. Land 2020, 9. $x$.

Lomax, T., and Warner, T. (2021). The legal basis for rights-based conservation in Liberia. Moreton-in-Marsh, Forest Peoples Programme (forthcoming).

Mau Ogiek. (2019). Submission to the Task Force on the Implementation of the Decision of the African Court on Human and Peoples' Rights Issued Against the Government of Kenya as gazetted by Notice 11215, 2 November 2018. Ogiek Peoples Development Programme, Nakuru.

McKeon, N., and Berron, G. (2020). Introduction to 'Reclaiming democracy from below: from the contemporary state capitalist system to peoples' sovereignty. Globalizations 2020, 17(7): 1241-1264.

Meijaard, E. et al. (2020). 'The environmental impacts of palm oil in context. Nature Plants 6: 1418-1426.

Menon, V. (2019). India: Rising tiger numbers and dwindling tribal rights. Pulitizer Center. Accessed at: https://pulitzercenter.org/ stories/india-risingtiger-numbers-and-dwindling-tribal-rights.

MRG (Minority Rights Group), RFUK (Rainforest Foundation UK) and Survival. (2020). 'NGO concerns over the proposes 30\% target for protected areas and absence of safeguards for Indigenous Peoples and local communities. MRG, London.

Namati. (2017). 'Community Land Protection. Facilitators Guide'. Washington DC. Namati.

Negretto, G., and Couso, J. (2018). Constitution-Building Processes in Latin America. International Institute for Democracy and Electoral Assistance, Stockholm.

Oldekop, J., Sims, K., and Birendra, K. (2019). Reductions in deforestation and poverty from decentralized forest management in Nepal. Nature Sustainability 2: 421-428.

OPDP (Ogiek Peoples Development Programme) \& Katiba Institute (2020). Defending our future. Overcoming the challenges of returning the Ogiek Home a report on implementing the Ogiek judgement in Kenya. Katiba Institute, Nairobi.
Pain, A., Marquardt, K., Lindh, A., Hasselquist, N.J. (2020). What is Secondary about Secondary Tropical Forest? Rethinking Forest Landscapes. Human Ecology. https://doi.org/10.1007/ s10745-020-00203-y.

Pathak, B., Yi, X., and Bohara, R. (2017). Community Based Forestry in Nepal: Status, Issues and Lessons Learned. International Journal of Sciences 2017 (6):119-129.

Peters, P., and Kambewa, D. (2007). 'Whose Security? Deepening Social Conflict over 'Customary' Land in the Shadow of Land Tenure Reform in Malawi' Cambridge, MA. CID Working Paper Series 2007.142, Harvard University.

Quizon, A., and Marquez, N. (eds). (2019). State of Land Rights and Land Governance in Eight Asian Countries. Asian NGO Coalition for Agrarian Reform and Rural Development, Manila.

Rainforest Concern. (2019). Colombia Yaogoje Apaporis. A Sacred Site Deep in the Amazon. At. https://www.rainforestconcern. org/projects/yaigoje-apaporis. Accessed 1 Oct 2020.

Reed, J., Deakin, L., Sunderland, T. (2014). What are 'Integrated Landscape Approaches' and how effectively have they been implemented in the tropics: a systematic map protocol. Environmental Evidence 4: 2.

Reed, J. Van Vianen, J., Deakin E., Barlow, J., Sutherland T. (2016). Integrated landscape approaches to managing social and environmental issues in the tropics: learning from the past to guide the future. Global Change Policy, 22(2016), 2540-2554. https://doi.org/10.1111/gcb.13284.

Republic of Kenya. (2009). Report of the Prime Minister's Task Force on the Conservation of the Mau Forest Complex. Prime Minister's Office, Nairobi.

Republic of Kenya. (2018a). Gazetted Forests in Counties as at February 2018. Kenya Forest Services, Nairobi.

Republic of Kenya. (2018b). Taskforce Report on Forest Resources Management and Logging Activities in Kenya. Ministry of Environment and Forests, Nairobi.

Republic of Kenya (2020). Taskforce on the Implementation of the Decision of the African Court on Human and Peoples Rights issued against the Government of Kenya in respect of the Rights of the Ogiek Community of Mau. Final Draft Report January 2020. Ministry of Environment and Forests, Nairobi.

Republic of Uganda. (2016). The State of Uganda's Forests 2016. Ministry of Water and Environment, Kampala.

RRI. (Rights and Resources Initiative). (2015a). Who Owns the World's Land? A global baseline of formally recognized indigenous \& community land rights. RRI, Washington DC.

RRI. (2015b). Protected Areas and the Land Rights of Indigenous Peoples and Local Communities. RRI, Washington DC.

RRI. (2018). At a Crossroads Consequential Trends in Recognition of Community-Based Forest Tenure from 2002-2017. RRI, Washington, DC.

RRI (2020a). Rights-Based Conservation: The Path to preserving Earth's biological and cultural diversity? Technical Report. RRI, Washington DC.

RRI (2020b). Estimate of the area of land and territories of Indigenous Peoples, local communities, and Afro-descendants where their rights have not been recognized'. Technical Report. RRI, Washington DC.

Sayer, J. ed. (2005). The Earthscan Reader in Forestry \& Development. Earthscan, London.

Seymour, F., La Vina, T. and Hite, K. (2014). Evidence Linking Community Level Tenure and Forest Condition. An Annotated Bibliography. Climate and Land Use Alliance, San Francisco.

The World Bank. (2019). Securing Forest Tenure Rights for Rural Development. An Analytical Framework. Program on Forests. The World Bank, Washington DC.

Thondhlana, G., and Cunhill, G. (2017). Local people and conservation officials' perceptions on relationships and conflicts in South 
African protected areas. International Journal of Biodiversity Science, Ecosystem Services and Management 13:1: 204-215.

Tseng, T. et al. (2021). Influence of land tenure interventions on human well-being and environmental outcomes. Nature Sustainability 4: 242-251. https://doi.org/10.1038/ s41893-020-00648-5.

UN. (2009). State of the World's Indigenous Peoples. Department of Economic and Social Affairs. United Nations, New York.

UN. (2015). The 17 Goals. Sustainable Development. Department of Economic and Social Development, United Nations, New York.

UN (United Nations). (2012). Resolution adopted by the General Assembly on 27 July 2021. A/RES/66/288. UN General Assembly, New York.

UNEP (United Nations Environmental Programme). (2020). Update of the Zero Draft of the Post-2020 Global Biodiversity Framework. CBD/POST2020/PREP/2/1. UNEP, Nairobi.

United Republic of Tanzania. (2011a). Guidelines for Participatory Forest Management. Ministry of Natural Resources and Tourism, Dar es Salaam.

United Republic of Tanzania. (2011b). Guidelines for Participatory Land Use Planning, Administration and Management in Tanzania. 2nd edn., Ministry of Lands, Housing and Human Settlement Development, Dar es Salaam.

United Republic of Tanzania. (2012). Participatory Forest Management in Tanzania. Facts and Figures. Ministry of Natural Resources and Tourism, Dar es Salaam.
Vallejos, P., Veit, P., Tipula, P., and Reytar, K. (2020). Undermining Rights. Indigenous Lands and Mining in the Amazon. World Resources Institute and RAISG, Washington DC.

Vasile, M. (2019). Community Owned Forests and Pastures in Romania. Submission to the Mau Ogiek Task Force, Kenya, 2 September 2019. Rachel Carson Center for Environment and Society, Munich.

Wainwright, J., and Bryan, J., (2009). Cartography, territory, property: post-colonial reflections on indigenous counter-mapping in Nicaragua and Belize. Cultural Geographies 16: 153-178.

WRI (World Resources Institute). (2021). 'We Lost a Football Pitch of Primary Rainforest Every 6 seconds in 2019. At: https://www. wri.org. Accessed 1 Feb 2021.

Xie, J. (2015). Collective Forests in China. Chinese Academy of Forestry World Forestry Institute, Beijing.

Young, H., and Goldman, L. (Eds). (2015). Livelihoods, Natural Resources and Post-Conflict Peacebuilding. Earthscan. Routledge, Oxford.

Zimmerman, B. (2019). Kayapo Owned Forests in Brazil' Submission to the Mau Ogiek Taskforce, Kenya. International Conservation Fund of Canada, Toronto.

Publisher's Note Springer Nature remains neutral with regard to jurisdictional claims in published maps and institutional affiliations. 